in vivo $33: 999-1010(2019)$

doi:10.21873/invivo.11569

Review

\title{
Potential Applications of Non-thermal Plasma in Animal Husbandry to Improve Infrastructure
}

\author{
TAEHO KWON ${ }^{1 *}$, NISANSALA CHANDIMALI $^{2,3^{*}}$, DONG-HO LEE $^{1 *}$, YEONGHOON SON $^{1}$, SEUNG-BIN YOON $^{1}$, \\ JA-RANG LEE ${ }^{1}$, SANGIL LEE ${ }^{1}$, KI JIN KIM ${ }^{1}$, SANG-YONG LEE ${ }^{1}$, SE-YONG KIM ${ }^{1}$, YU-JIN JO ${ }^{1}$, \\ MINSEONG KIM ${ }^{1}$, BYOUNG-JIN PARK ${ }^{1}$, JUN-KI LEE ${ }^{1}$, DONG KEE JEONG ${ }^{3}$ and JI-SU KIM ${ }^{1}$ \\ ${ }^{1}$ Primate Resources Center, Korea Research Institute of Bioscience and Biotechnology (KRIBB), \\ Jeonbuk, Republic of Korea; \\ ${ }^{2}$ Immunotherapy Convergence Research Center,Korea Research Institute of Bioscience and Biotechnology (KRIBB), \\ Daejeon, Republic of Korea; \\ ${ }^{3}$ Laboratory of Animal Genetic Engineering and Stem Cell Biology, Advanced Convergence Technology \& Science, \\ Jeju National University, Jeju, Republic of Korea
}

\begin{abstract}
Infrastructure in animal husbandry refers to fundamental facilities and services necessary for better living conditions of animals and its economy to function through better productivity. Mainly, infrastructure can be divided into two categories: hard infrastructure and soft infrastructure. Physical infrastructure, such as buildings, roads, and water supplying systems, belongs to hard infrastructure. Soft infrastructure includes services which are required to maintain economic, health, cultural and social standards of animal husbandry. Therefore, the proper management of infrastructure in animal husbandry is necessary for animal welfare and its economy. Among various technologies to
\end{abstract}

This article is freely accessible online.

*These Authors contributed equally to this work.

Correspondence to: Taeho Kwon, Ph.D., Primate Resources Center, Korea Research Institute of Bioscience and Biotechnology (KRIBB), 351-33 Neongme-gil, Ibam-myeon, Jeongeup-si, Jeonbuk, 56216, Republic of Korea. Tel: +82 635705316, Fax: +82 635705309, e-mail: kwon@kribb.re.kr; Dong Kee Jeong, Ph.D., Department of Animal Biotechnology, Faculty of Biotechnology, Jeju National University, 102 Jejudaehak-ro, Jeju-si, Jeju-do, 63243, Republic of Korea. Tel: +82647543331, Fax: +82 647252403, e-mail: newdkjeong@ gmail.com; Ji-Su Kim, Ph.D., Primate Resources Center, Korea Research Institute of Bioscience and Biotechnology (KRIBB), 351-33 Neongme-gil, Ibam-myeon, Jeongeup-si, Jeonbuk, 56216, Republic of Korea. Tel: +82 635705300, Fax: +82 635705309, e-mail: kimjs@kribb.re.kr

Key Words: Animal husbandry, infrastructure, non-thermal plasma, technology, products, review. improve the quality of infrastructure, non-thermal plasma (NTP) technology is an effectively applicable technology in different stages of animal husbandry. NTP is mainly helpful in maintaining better health conditions of animals in several ways via decontamination from microorganisms present in air, water, food, instruments and surfaces of animal farming systems. Furthermore, NTP is used in the treatment of waste water, vaccine production, wound healing in animals, odorfree ventilation, and packaging of animal food or animal products. This review summarizes the recent studies of NTP which can be related to the infrastructure in animal husbandry.

Animal husbandry, a component of modern agriculture, concerns with the animals that are raised for commodities such as meat, milk, eggs, fur, leather and wool. The wellbeing of animals in animal husbandry has ethical, scientific, political and aesthetic components which are required for a better animal management, welfare, handling, care and high productivity (1). Infrastructure is one of the major contributors to well-being of animals which usually associates with management issues regarding nutrition, health, transportation, mustering and handling and other special invasive practices (2). Infrastructure refers to the fundamental facilities in an animal husbandry which can be divided into hard infrastructure and soft infrastructure. Hard infrastructure includes systems such as buildings, roads, and water supplying systems. Soft infrastructure consists of costeffective, health, social and cultural facilities. Therefore, the better management of infrastructure in animal husbandry leads to well-being of animals and higher financial profit through the higher productivity. 
Non-thermal plasma (NTP) has been identified as a potential approach to improve the quality of infrastructure systems and facilities including buildings, medications, food, ventilation, water supply, instruments and other special management practices (3-7). NTP is partially ionized matters in gaseous state at low temperatures and energy is mostly stored in free electrons (8). Different devices have been introduced to generate NTP including dielectric barrier discharges (DBD), atmospheric plasma jets, coronas and, surface and microwave discharges for numerous applications in different fields (9). NTP is environment-friendly, free of toxicity and requires a low temperature. These characteristics of NTP do not put animals and environment in animal husbandry at risk $(10,11)$. Therefore, NTP can be considered as an effective potential application to improve infrastructure, without disturbing animal well-being.

In this review, we summarized the already known applications of non-thermal plasma in the infrastructure sector of animal husbandry with regard to the well-being of animals and higher productivity which is necessary for its financially profitable function. We also highlighted the studies about the applications of NTP for improving infrastructure in other fields and hypothesized its use in animal husbandry. However, more systematic research is still required to bridge knowledge gaps particularly on NTP and the infrastructure of animal husbandry.

\section{Role of NTP in Bio-decontamination to Provide a Healthy Environment for Farm Animals}

The presence of various micro-organisms such as bacteria, biofilms, fungi, spores of fungi and protozoan parasites and their genes and metabolites in the environment increases the health risks to farm animals by causing and spreading numerous diseases $(12,13)$. Therefore, bio-decontamination of surfaces, instruments and water is necessary in animal husbandry to maintain a healthy environment. Several methods have been introduced for this purpose including oven or autoclave sterilization processes, chemical sterilization such as ethylene oxide sterilization, Gamma irradiation, high hydrostatic pressure technique and microwave sterilization. The limitations of these techniques such as the possibility of chemicals to remain after sterilization, requirement of complex, expensive and high security equipment and the requirement of special conditions for operations have also been discussed $(14,15)$. Therefore, NTP has been suggested as an effective, less toxic and lowcost method for bio-decontamination by several research groups. Also, none of the destructive effects on decontaminated surfaces were detected following NTP treatment $(14,16,17)$. Furthermore, NTP can be used to decontaminate heat-sensitive surfaces and instruments as it is used at room temperature (18).
Commonly, most decontamination techniques target the membrane of a cell as it separates its inner compartments from the environment (14). NTP has general and specific effects on the cell surface of living organisms (14, 19-21). In addition to cell membranes $(14,22-26)$, NTP targets DNA $(14,24,26,27)$ and proteins $(14,26,28)$ to destroy living organisms (Table I).

\section{High-touch and Frequently-touched Surfaces and Instruments Can Be Decontaminated by NTP in Animal Farms}

Poor health conditions of farm animals disturb animal wellbeing and result in poor productivity and economic losses. Therefore, health and hygiene of farm animals, which comes under the category of soft infrastructure, must be maintained properly. "High-touch" or frequently touched surfaces and instruments are easily contaminated and should be decontaminated for a pathogen-free environment $(15,16)$.

To date, NTP has been identified as an effective, low-cost and non-toxic way to decontaminate surfaces, instruments and confined environments $(15,16,29)$. It has been shown that NTP produced from single-jet system eradicates vegetative bacteria from different surfaces $(16,30)$ and NTP from multi-jet system is capable of reducing surface pathogens such as methicillin-resistant staphylococcus aureus, Clostridium difficile, Escherichia coli, Pseudomonas aeruginosa, Klebsiella pneumoniae and Acinetobacter baumannii (16). Furthermore, other studies have also demonstrated the successful decontamination of surfaces and instruments from these pathogenic organisms by NTP treatment $(6,15)$. Therefore, NTP can be used in the decontamination of animal farm environments as these pathogens are breeding health risks for animals (13, 31-35). It has also been reported that exposure to NTP over a short period inactivates micro-organisms in confined environments such as airtight boxes and refrigerators, suggesting that NTP can be used to keep stored agricultural products fresh (29). Another study has suggested that NTP generated from pure oxygen is more effective for decontamination than that generated from oxygen-hydrogen gas mixture (18).

Moreover, NTP is able to inactivate micromycete species such as Cladosporium sphaerospermum, Aspergillus oryzae, Alternaria species and Byssochlamys mivea and micromycete spores $(36,37)$. This fungicidal property of NTP also suggests its usefulness in decontaminating animal farms. The antibacterial efficacy of NTP has been further confirmed by several groups $(4,30,38-40)$. NTP has been found to have antibacterial effects on a variety of bacteria $(41,42)$, on ESKAPE pathogens in the environment (17), on multi-drugresistant bacteria in surface environments (43). Moreover, NTP has been shown to suppress host-cell invasion and to deactivate cell motility of Salmonella Typhimurium (44). 
Table I. Effects of NTP on microbial constituents to destroy micro-organisms.

\begin{tabular}{|c|c|c|c|}
\hline Constituent of micro-organism & Action of plasma & Effects on micro organism & Ref. \\
\hline \multirow[t]{2}{*}{ Cell surface } & Intense bombardment by radicals & $\begin{array}{l}\text { Provoke surface lesions that micro-organisms } \\
\text { cannot repair sufficiently }\end{array}$ & $(14,19-21)$ \\
\hline & "Etching" process & $\begin{array}{l}\text { Form volatile compounds by adsorbing plasma components } \\
\text { Destroy spores }\end{array}$ & \\
\hline \multirow[t]{2}{*}{ Cell membrane } & Induce perforation & Increase the number of pores formed in cell membrane & $(14,22-26)$ \\
\hline & $\begin{array}{l}\text { Increase transmembrane } \\
\text { permeability }\end{array}$ & $\begin{array}{l}\text { Affect the transmembrane potential and destroy } \\
\text { the intracellular } \mathrm{pH} \text { regulation }\end{array}$ & \\
\hline \multirow[t]{3}{*}{ DNA } & $\begin{array}{l}\text { Breakdown of the interaction } \\
\text { between membrane } \\
\text { protein and DNA }\end{array}$ & Increase the release of DNA & $\begin{array}{c}(14,24 \\
26,27)\end{array}$ \\
\hline & & $\begin{array}{l}\text { Leakage of DNA from the cell through } \\
\text { plasma-formed pores in membrane }\end{array}$ & \\
\hline & & Partial hydrolysis of DNA & \\
\hline Proteins & Oxidative processes & Affect the enzyme system & $(14,26,28)$ \\
\hline
\end{tabular}

Other than vegetative cells, NTP has the ability to decontaminate surfaces from biofilms which are responsible for undesirable effects such as equipment damages and pipe plugging and cannot be destroyed by conventional sterilization methods. Moreover, NTP can destroy endotoxins, lipids and prions of microorganisms (45-50).

Even though, most of these studies were conducted in hospital environments and on medical devices, their results are applicable for all environments and instruments contaminated with above mentioned pathogenic microorganisms. Therefore, NTP is an effective and low-cost technology for surface and equipment decontamination in animal farms without any adverse effects to animals or farm environment.

\section{NTP Increases the Microbiological, Physical and Chemical Quality of Water via Inactivating Micro-organisms}

The quality of water can affect animal health and productivity directly and indirectly. Therefore, ensuring the microbiological, chemical and physical quality of water which is used for any purpose in a farm is an important management practice under the infrastructure section of animal farming (51).

As an effective method of water sterilization, NTP has been shown to successfully inactivate $E$. coli as a model bacterium in water (52). The same study has shown that bacteria cells enter to an active-but-nonculturable state after exposure to argon plasma jet-generated NTP. Membrane damages were also observed, suggesting that bacterial inactivation may be due to the peroxidation of cell membrane lipids by NTP-produced ROS (52). Another study has found that NTP is a cost-effective, environmentally friendly, sustainable and non-chemical-based promising candidate to destroy microcystins in water which cannot be destroyed by conventional methods. Microcystins are toxins produced by cyanobacteria, and can cause detrimental effects on farm animal health (53). Moreover, DBD-generate -NTP has been shown to inactivate residues of cyanobacteria which cause algal bloom in water (54). Another study has reported that pulsed plasma gas discharge destroys waterborn enteroparasites which infect both farm animals and humans. According to that study plasma treated water kills the parasite at the thick-walled oocyst stage which is highly resistant to chlorine (55). It has been reported from another research group that plasma has a selective impact on bacterial populations at lower doses and potent bactericidal effects at high doses (56).

Altogether, these studies have shown that NTP is an effective method to keep water quality in a standard level to maintain animal health in animal husbandry.

\section{NTP Degrades the Organic Contaminants in Waste Water Effluents}

Waste management is one of the key infrastructure facilities in the field of livestock. The release of waste water effluents without proper management from industries, agricultural systems and animal farms has gained attention as a major cause of aquatic environment pollution. Waste water effluents from animal farms contain animal slurry, milk, hormones, medication drugs, pharmaceutical compounds and food wastes (57). Even though, the conventional water treatment methods destroy some of these pollutants, fail to degrade most of persistent substances and micro pollutants in waste water (58).

Therefore, various advanced oxidation processes were introduced during the last decades for the treatment of waste water including electric discharge NTP technology (59). According to previous studies, active species of NTP such as 
ions, radicals, molecular species, atoms, UV light and shock waves are contributing to the removal of pollutants without requiring any additional chemicals. The efficiency of NTP treatment on waste water depends on the gas composition used to generate NTP, the power applied and the temperature of the solution (60-64). A study has shown that the application of NTP to degrade antibiotics of the penicillin class such as amoxicillin, oxacillin and ampicillin which are widely used in veterinary medicine for the treatment of bacterial infections in animals (65). NTP has also shown synergistic effects with micro pollutant adsorption in the decomposition of pesticides in waste water such as atrazine, which can be released from animal husbandry (58).

Moreover, NTP can be used to degrade sulfonamide antibiotics in waste water (66). Sulfonamides are widely used in veterinary medicine practices as effective chemotherapeutics for protozoan and bacterial infections. But, it has a maximum residue limit due to the carcinogenic potency of sulfonamide residues (67). Also, animal antibiotics are considered as non-biodegradable pollutants due to their adverse effects and toxicity to ecosystems (65). Therefore, it is necessary to degrade the sulfonamides in waste water. A previous study has introduced an aerationassisted NTP to degrade these non-biodegradable sulfonamides (66). According to another study, NTP mineralizes organic pollutants in waste water such as Irgarol 1051 which is an algaecide found in antifouling paints (68). An NTP-ozonation system has been successfully tested for the degradation of herbicides and pesticides in waste water. Herbicides and pesticides are used to destroy unwanted vegetation and pests in farming systems (69). Farm waste water effluents may include significant amounts of palm oil, used in animal nutrition, and of its derivatives $(70,71)$. Gliding arc discharge NTP has been shown to degrade palm oil pollutants in waste water (59)and to reduce more than $50 \%$ of total organic carbon (TOC) (59). Post-treatment of plasma to aryl containing water increased the effectiveness of biological removal (72).

All these studies provided great evidence showing that NTP alone or in combination with other operation systems has the ability to degrade organic contaminants in waste water effluents from indoor or outdoor animal farming systems.

\section{NTP Abates the Emission of Harmful Volatile Organic Compounds (VOC) and Offensive Odors from Indoor and Outdoor Animal Farming Systems}

Volatile organic compounds (VOCs), organic chemicals which produce vapors at room temperature, are not acutely toxic. However, they cause short- or long-term adverse health effects to animals and humans (73). Many types of VOCs including carboxylic acids, alcohols, carbonyls, phenolic compounds and sulfur and nitrogen-containing compounds are emitted to the environment in animal husbandry mainly due to feeding operations such as storage and handling, animal wastes and exhalation (74-76).

Few technologies have been introduced to control the emission of VOCs and odors such as adsorption, absorption, condensation, thermal and catalytic incineration and biological oxidative filtering (77). Recent studies have suggested that NTP is a better treatment technology for VOC emission abatement (78-80) due to the advantages of requiring relatively low energy, having moderate cost, being easily operated, having short residence time and the ability to treat relatively low concentrations of VOCs at low operating temperatures $(81,82)$. Furthermore, previous studies have tested the application of NTP for abatement of numerous hazardous air pollutants such as sulfur dioxide (SO2) (83), Nitrogen dioxide and nitric oxide (NO), odors (H2S, NH3) (84-86), chlorofluorocarbons (CFCs) and Mercury $(87,88)$.

NTP generates strong oxidants in the gas phase and therefore, is a source of gas-phase reactive species and free radicals such as $\mathrm{O}^{-}, \mathrm{OH}^{-}$and $\mathrm{H}^{+}$which are contributing to the elimination of air pollutants. These reactive species and radicals are able to react with odors, vapors and toxic gases and convert them into non-toxic molecules (89, 90). Furthermore, some studies have introduced synergistic methods to abate VOCs like NTP coupled with F$\mathrm{TiO} 2 /$ gamma-Al2O3 for the removal of toluene odor (91) and NTP combined with bio trickling filters (BTF) for the removal of dimethyl sulfide (DMS) (92).

Taken together, it has been demonstrated that NTP is an effective technology of care for the health of animals in confined indoor environments by abating VOC and offensive odors. It also controls the air pollution in outdoor environments. Therefore, it can be concluded that NTP is a helpful technology to manage animal health as one component of soft infrastructure and ventilation in buildings as a component of hard infrastructure.

\section{NTP Is an Effective Inactivating Agent for Preparation of Conventional Inactivated Vaccines}

Vaccines can be categorized under the section of health in soft infrastructure. Vaccines are considered a predominant method of controlling various diseases in livestock industry. Conventional inactivated vaccines, live attenuated vaccines and gene-mutated vaccines are the three types of vaccines used in animals $(93,94)$. Among these vaccines, inactivated vaccines are considered the most popular vaccines in animal husbandry (95). Usually, the inactivated vaccines rely on inactivating agents. However, the deleterious effects of those agents such as formaldehyde and beta-propiolactone 
compromise safety and effectiveness of vaccines $(11,96)$. Therefore, NTP has introduced as an effective and safe agent to produce inactivated vaccines (11).

It has already been reported the preparation of vaccines against Newcastle disease virus (NDV) and Avian influenza virus (AIV) using NTP as inactivating agent (11). Newcastle disease and Avian influenza are two common diseases which affect a variety of animal species and cause $100 \%$ mortality (97). A previous study has shown that treatment for a certain time period with NTP is suitable for these vaccine preparations (11). The same study has reported that overdose of NTP destroys virus morphology, decreases virulence, and causes loss of immunogenicity. Therefore, determination of the specific dose and time of NTP treatment is necessary for the preparation of inactivated vaccines (11). According to the above study, inactivation of virus by NTP treatment is due to increased oxidation reduction potential (ORP) through a series of chemical reactions among ROS and RNS in the allantoic fluid system of virus (11).

Taken together, these findings suggest that NTP can be used as a successful, effective and safe inactivating agent for inactivated vaccine preparation against viruses affecting animal husbandry. Therefore, NTP indirectly contributes to management of animal health which is a component of soft infrastructure.

\section{NTP Is a Promising Approach to Preserve Fresh and Minimally Processed Animal Feed}

Most of fresh or partially processed food products are perishable due to the higher concentration of moisture and ease to spoil specially during storage due to contamination with microorganisms or due to higher chemical/biochemical reactions (98). Most of the times, fresh and partially processed food is given to farm animals which consume it raw. Therefore, it is necessary to preserve the quality of the food and prevent food-borne diseases within animal herds. NTP has been introduced as an effective treatment for this purpose by previous studies. They have shown the ability of NTP to decontaminate food and extend the shelf-life of food (98-102). NTP also inactivates thermophilic bacteria which cannot be destroyed by conventional methods. NTP achieves this by modifying the structure of thermophilic proteins (103). Few studies have shown that NTP inactivates bacteria on fresh food, with special focus on Salmonella species which can adversely affect farm animals and humans (104, 105). Another study has specially shown the favorable effects of NTP on raw milk. Milk is a product which can easily get contaminated due to its fresh nature and high nutritious value. Therefore, the elimination of bacteria from milk is a serious problem for decades. However, NTP has been shown to be able to reduce bacteria in milk, using $E$. coli as model bacteria (106). This study demonstrated the applicability of NTP in animal husbandry as milk is used to feed new born and young animals such as cattle, goats, and humans. Thus, low-cost NTP can be used to produce good quality milk and provide financial benefits for animal husbandry. NTP also inactivates the spores including chemical and heat-resistant spores which are produced by spore-forming microorganisms (107).

Contamination of animal feed and feed raw materials by fungi, especially, during storage is also common in animal husbandry (108). A previous study has shown that NTP prolongs the shelf life of food by reducing the deterioration of food through inactivation of fungi $(109,110)$. In addition to the inactivation of microorganisms, NTP also preserves food by removing pesticides and insecticides from food surfaces without harming it (111). Thus, NTP plays another important role in animal husbandry by removing toxic materials from raw plant materials which are consumed by farm animals.

Taken together, all studies have demonstrated that NTP treatment is an effective technology to preserve animal feed by increasing its quality, inactivating microbes, preventing spoilage and removing toxic materials. Therefore, NTP contributes to soft infrastructure indirectly via food preservation.

\section{Roles of NTP in Skin Decontamination, Skin Renewal and Skin Wound Healing in Animals}

NTP has a greater potential in efficient painless disinfection of skins, sterilization even in microscopic openings of the skin, wound healing, therapy of skin infections and tissue regeneration without damaging healthy tissues $(112,113)$. Gaseous stage NTP allows it to penetrate even inhomogeneous surfaces, civilities and fissures up to micro scale. Therefore, NTP provides advantage over traditional fluids or chemicals used for the same purpose (113).

It has been reported that NTP generated from atmospheric pressure plasma jet and DBD has the ability to decontaminate skins (114) and to inactivate Chlamydia trachomatis, which causes different diseases in farm animals, especially in cattle (115). Moreover, several studies have demonstrated the wound healing ability of NTP. According to those studies, NTP supports wound healing by its antiseptic effects, by regulating integrin receptors on the surface of skin cells, by its pro-angiogenic effects, by promoting vascularization, by controlling blood coagulation, by boosting and prolonging the cutaneous microcirculation and by sterilizing the wounds without any observable side effects (116-122). Some of these studies have used skins from animals such as porcine and rat to show that NTP decontaminates animal skins or supports wound healing (120, 122).

Continuous proliferation and differentiation of epidermal cells of the skin are required for maintaining healthy skin. 
They are also essential for a better and fast healing of wounds caused from injuries, ulcers or tumor removal (123, 124). A study has demonstrated that NTP can be employed in skin regenerating (125). It was shown that NTP allows keratinocytes to escape from G1 cell cycle arrest, increases the cell proportion in S and G2 phases, causes translocation of beta-catenin to nucleus and induces the transcription of target genes without damaging DNA (125). Moreover, another study has tested the effects of cold argon plasma on eggs of blow fly (126). Larvae of this fly produce myiasis which is a parasitic infection where larvae grow inside the host while feeding on its tissues. According to that study, NTP treatment on blow fly egg shells supported healing of these wounds (126).

Taken together, NTP is a promising effective technique to decontaminate, treat wounds and renew skins of farm animals and provide better health and hygiene of animals as part of soft infrastructure management.

\section{NTP Inactivates Bio-aerosols Rapidly and Facilitates a Disease-free Ventilation in Farm Environment}

Particles of biological origin such as microorganisms (fungi, bacteria and virus), pollen, allergens, endotoxins, plant debris and skin scales are considered as bio-aerosols (127). These bio-aerosols are reported to have adverse health effects in animals and humans (128). Therefore, the maintenance of air without bio-aerosols is necessary for healthy environmental conditions in an animal farm. Commonly, the particulate filters inside heating, ventilating and air-conditioning (HVAC) systems are used to control bio-aerosols (129). However, the efficiency of these filters is doubtable as the collected bio-aerosols are not inactivated and accumulate on the surfaces of filters. In addition, bio-aerosols proliferate during long periods (128). Therefore, as another method of air-sterilization, NTP has been investigated in previous studies $(3,128,130,131)$. It is more advantageous over other methods as it does not produce secondary environmental pollution and is cost effective (132).

One of those studies has reported that NTP generated from DBD deactivates indoor and outdoor bio-aerosols by reducing culturability, viability and diversity of microorganisms. Bacteria inactivation reached $95 \%$ and that of fungi $85-98 \%$ (128). Another study has demonstrated that NTP efficiently inactivates airborne pathogens which are resistant to antibiotics. According to that study the efficacy of NTP depends on the load of microorganisms, and the generation rate and flow rate of bio-aerosols. As the underlying mechanism of this inactivation, they suggested two key regulatory oxidative stress pathways which are mediated by superoxide dismutase and catalase (133). Another study has introduced a reliable bio-aerosol filter which is not requiring any maintenance practices as it made by NTP (3).

NTP has also been demonstrated to inactivate various airborne viruses including MS2 virus and adenoviruses (8, $132,134)$. This inactivation is primarily attributed to ROS released from NTP and the subsequent damage of virus proteins and genes (132).

According to this evidence, NTP is an applicable technology for indoor and outdoor air cleaning in animal farms as a cost-effective method to manage soft infrastructure.

\section{Usage of NTP to Disinfect Packaging Materials and Inside of Sealed Packages}

Food Packaging is an important aspect in animal husbandry as it uses packaged feed for feeding animals in farms and packages to pack their products for commercialization purposes. Therefore, usage of sterilized packing materials or disinfection of the inside of packages is essential to preserve food products from microorganisms and to extend the shelflife of fresh products. NTP has been introduced as a sterilization method with numerous advantages over other conventional methods. Low operational cost, short treatment time, low temperatures, and non-toxicity make NTP an applicable disinfectant technique for variety of materials including heat and chemical sensitive materials $(8,135)$.

Few studies have examined the use of NTP in disinfecting the inside of sealed packages (135-137). One of these studies demonstrated the inactivation of high concentration of $E$. coli within few seconds in liquids contained inside sealed bags by NTP (135). Another study has introduced a DBD system to generate NTP inside packages containing cherry tomatoes. In this set-up of DBD systems the package itself serves as the dielectric material. According to that study, this set-up helps to preserve food products without disturbing their quality (137). A device to generate NTP inside sealed bags has been introduced by another study to sterilize single-use medical devices (136). It has been shown that NTP increases the shelflife of packaged chicken fillets without any adverse effects (138). In addition to disinfection of the insides of sealed bags, some studies have shown that NTP disinfects packaging materials. According to these studies, the physicochemical and biodegradable properties of food packaging materials such as polylactic acid films can be improved through NTP treatment without negatively affecting these materials $(8,139)$.

Altogether, these studies indicate that NTP can be used to sterilize and disinfect the insides of sealed packages and improve the properties of packaging materials which are used to preserve food. Also, NTP protects the quality of foods inside packages without any adverse effects on packaging materials. Therefore, this can be considered as another application of NTP to manage soft infrastructure in animal husbandry. 


\section{Conclusion and Future Perspective}

The studies highlighted in this review are focused on nonthermal plasma (NTP) technology as an emerging and effective technology in the field of infrastructure. NTP is produced from different devices such as DBD, plasma jet, coronas, and surface and microwave discharges. These studies were conducted in the field of animal husbandry as well as in other fields, such as medicine. Therefore, in this review we summarized the results of the application of NTP in the infrastructure of animal husbandry and we hypothesized the potential application of NTP in animal husbandry from the knowledge in other fields. Thus, further studies are needed on the application of NTP in the infrastructure of animal husbandry.

As a summary, NTP is a technology that can effectively be applied in infrastructure management over other technologies due to its environmentally friendly nature and low cost which is also a main part of infrastructure. Other than the economy, NTP provides better living conditions to animals by contributing to the maintenance of animal health, quality of nutrition and animal welfare. Better living conditions of animals also provides economic advantages through higher productivity. Therefore, NTP can be used for the proper management of infrastructure in animal husbandry.

\section{Summary}

Animal husbandry is one of the branches of agriculture which consists of animals that are raised for several commodities such as meat, milk, eggs, fiber or other products. Usually, it includes the day-to-day care of animals, rising of the livestock and selective breeding. A wide range of animal species such as cattle, sheep, goats, pigs, chickens, and rabbits are used in animal husbandry in different parts of the world. Moreover, insect farming and aquaculture are also considered part of animal husbandry. One of the main requirements in animal husbandry is the maintenance of better living conditions of animals for animal welfare and higher financial gains through higher productivity. Proper management of infrastructure is essential to provide those better living conditions of animals. Among various technologies, non-thermal plasma technology is gaining attention as an effective technology to improve the infrastructure at several stages of the production system in animal husbandry.

\section{Conflicts of Interest}

The Authors declare that there are no conflicts of interest.

\section{Author's Contributions}

T.K., N.C., D.K.J., and J.S.K., designed and wrote the whole manuscript; T.K., N.C, performed the figures; D.H.L., S.B.Y.,
J.R.L., Y.S., S.L., K.J.K., S.Y.L. S.Y.K., Y.J.J., M.K., B.J.P., J.K.L., contributed in the revision of the manuscript. All Authors read and approved the final manuscript.

\section{Acknowledgements}

This study was supported by grants from the KRIBB Research Initiative Program (KGM5161914). This research was supported by Basic Science Research Program through the National Research Foundation of Korea (NRF) funded by the Ministry of Education (2017R1D1A1B03028188), KRIBB-OGM5201922.

\section{References}

1 Swanson JC: Farm animal well-being and intensive production systems. J Anim Sci 73(9): 2744-2751, 1995. PMID: 8582867.

2 Petherick JC: Animal welfare provision for land-based livestock industries in australia. Aust Vet J 84(11): 379-383, 2006. PMID: 17092321. DOI: 10.1111/j.1751-0813.2006.00064.x

3 Jidenko $\mathrm{N}$ and Borra JP: Self-cleaning, maintenance-free aerosol filter by non-thermal plasma at atmospheric pressure. $\mathrm{J}$ Hazard Mater 235-236: 237-245, 2012. PMID: 22951224. DOI: 10.1016/j.jhazmat.2012.07.055

4 Sung SJ, Huh JB, Yun MJ, Chang BM, Jeong CM and Jeon YC: Sterilization effect of atmospheric pressure non-thermal air plasma on dental instruments. J Adv Prosthodont 5(1): 2-8, 2013. PMID: 23508991. DOI: 10.4047/jap.2013.5.1.2

5 Magureanu M, Piroi D, Mandache NB, David V, Medvedovici A and Parvulescu VI: Degradation of pharmaceutical compound pentoxifylline in water by non-thermal plasma treatment. Water Res 44(11): 3445-3453, 2010. PMID: 20398913. DOI: 10.1016/j.watres.2010.03.020

6 Burts ML, Alexeff I, Meek ET and McCullers JA: Use of atmospheric non-thermal plasma as a disinfectant for objects contaminated with methicillin-resistant staphylococcus aureus. Am J Infect Control 37(9): 729-733, 2009. PMID: 19559504. DOI: $10.1016 /$ j.ajic.2009.03.010

7 Schnabel U, Handorf O, Yarova K, Zessin B, Zechlin S, Sydow D, Zellmer E, Stachowiak J, Andrasch M, Below H and Ehlbeck J: Plasma-treated air and water-assessment of synergistic antimicrobial effects for sanitation of food processing surfaces and environment. Foods 8(2), 2019. PMID: 30717375. DOI: $10.3390 /$ foods 8020055

8 Scholtz V, Pazlarova J, Souskova H, Khun J and Julak J: Nonthermal plasma - a tool for decontamination and disinfection. Biotechnol Adv 33(6 Pt 2): 1108-1119, 2015. PMID: 25595663. DOI: 10.1016/j.biotechadv.2015.01.002

9 Zhang JJ, Wang XZ, Luong Do H, Chandimali N, Kang TY, Kim N, Ghosh M, Lee SB, Mok YS, Kim SB, Kwon T and Jeong DK: Microrna-7450 regulates non-thermal plasmainduced chicken sertoli cell apoptosis via adenosine monophosphate-activated protein kinase activation. Sci Rep 8(1): 8761, 2018. PMID: 29884805. DOI: 10.1038/s41598-01827123-8

10 El Roz M, Lakiss L, Valtchev V, Mintova S and ThibaultStarzyk F: Cold plasma as environmentally benign approach for activation of zeolite nanocrystals. Microporous Mesoporous Mater 158: 148-154, 2012. DOI: 10.1016/j.micromeso. 2012. 03.003 
11 Wang G, Zhu R, Yang L, Wang K, Zhang Q, Su X, Yang B Zhang $J$ and Fang J: Non-thermal plasma for inactivatedvaccine preparation. Vaccine 34(8): 1126-1132, 2016. PMID: 26529075. DOI: $10.1016 /$ j.vaccine. 2015.10 .099

12 Rodrigues Hoffmann A, Proctor LM, Surette MG and Suchodolski JS: The microbiome: The trillions of microorganisms that maintain health and cause disease in humans and companion animals. Vet Pathol 53(1): 10-21, 2016. PMID: 26220947. DOI: 10.1177/0300985815595517

13 Holland RE: Some infectious causes of diarrhea in young farm animals. Clin Microbiol Rev 3(4): 345-375, 1990. PMID: 2224836.

14 Moreau M, Orange N and Feuilloley MG: Non-thermal plasma technologies: New tools for bio-decontamination. Biotechnol Adv 26(6): 610-617, 2008. PMID: 18775485. DOI: 10.1016/ j.biotechadv.2008.08.001

15 Cahill OJ, Claro T, O'Connor N, Cafolla AA, Stevens NT, Daniels $\mathrm{S}$ and Humphreys $\mathrm{H}$ : Cold air plasma to decontaminate inanimate surfaces of the hospital environment. Appl Environ Microbiol 80(6): 2004-2010, 2014. PMID: 24441156. DOI: 10.1128/AEM.03480-13

16 Cahill OJ, Claro T, Cafolla AA, Stevens NT, Daniels S and Humphreys H: Decontamination of hospital surfaces with multijet cold plasma: A method to enhance infection prevention and control? Infect Control Hosp Epidemiol 38(10): 1182-1187, 2017. PMID: 28793943. DOI: 10.1017/ice.2017.168

17 Flynn PB, Higginbotham S, Alshraiedeh NH, Gorman SP, Graham WG and Gilmore BF: Bactericidal efficacy of atmospheric pressure non-thermal plasma (apntp) against the eskape pathogens. Int J Antimicrob Agents 46(1): 101-107, 2015. PMID: 25963338. DOI: 10.1016/j.ijantimicag. 2015.02.026

18 Boscariol MR, Moreira AJ, Mansano RD, Kikuchi IS and Pinto TJ: Sterilization by pure oxygen plasma and by oxygen-hydrogen peroxide plasma: An efficacy study. Int J Pharm 353(1-2): 170175, 2008. PMID: 18207677. DOI: 10.1016/ j.ijpharm.2007.11.059

19 Pelletier J: La sterilization par le procede plasma Aggressologie 33: 105-110, 1993. PMID: 1340091.

20 Laroussi $\mathrm{M}$ and Leipold F: Evaluation of the roles of reactive species, heat, and uv radiation in the inactivation of bacterial cells by air plasmas at atmospheric pressure. Int J Mass Spec 233(1-3): 81-86, 2004. DOI: 10.1016/j.ijms.2003.11.016

21 Lerouge S, Wertheimer MR, Marchand R, Tabrizian M and Yahia LH: Effect of gas composition on spore mortality and etching during low- pressure plasma sterilization. J Biomed Mater Res 51(1): 128-135, 2000. PMID: 10813754.

22 Ulmer HM, Heinz V, Gänzle MG, Knorr D and Vogel RF: Effects of pulsed electric fields on inactivation and metabolic activity of lactobacillus plantarum in model beer. J Applied Microbiol 93(2): 326-335, 2002. PMID: 12147082.

23 Spilimbergo S, Dehghani F, Bertucco A and Foster NR: Inactivation of bacteria and spores by pulse electric field and high pressure co2 at low temperature. Biotechnol Bioeng 82(1): 118-125, 2003. PMID: 12569631. DOI: 10.1002/bit.10554

24 Ohshima T, Sato $M$ and Saito $M$ : Selective release of intracellular protein using pulsed electric field. J Electrostat 35(1): 103-112, 1995. DOI: 10.1016/0304-3886(95)00014-2

25 Moreau M, Feuilloley MGJ, Orange N and Brisset JL: Lethal effect of the gliding arc discharges on erwinia spp. J Appl Microbiol 98(5): 1039-1046, 2005. PMID: 15836472. DOI: $10.1111 / \mathrm{j} .1365-2672.2004 .02535 . \mathrm{x}$
26 Moreau M, Feuilloley MGJ, Veron W, Meylheuc T, Chevalier $\mathrm{S}$, Brisset JL and Orange N: Gliding arc discharge in the potato pathogen erwinia carotovora subsp. Atroseptica: Mechanism of lethal action and effect on membrane-associated molecules. Appl Environ Microbiol 73(18): 5904-5910, 2007. PMID: 17644644. DOI: 10.1128/AEM.00662-07

27 Elmnasser N, Guillou S, Leroi F, Orange N, Bakhrouf A and Federighi M: Pulsed-light system as a novel food decontamination technology: A review. Can J Microbiol 53(7): 813-821, 2007. PMID: 17898836. DOI: 10.1139/W07-042

28 Igumenov VL, Sharonov BP and Pasechnik VA: Aggregation of membrane proteins of e. Coli cells after treatment with singlet oxygen. Biokhimiya 53(6): 925-930, 1988. PMID: 3052597.

29 Heo NS, Lee MK, Kim GW, Lee SJ, Park JY and Park TJ: Microbial inactivation and pesticide removal by remote exposure of atmospheric air plasma in confined environments. J Biosci Bioeng 117(1): 81-85, 2014. PMID: 23850266. DOI: 10.1016/j.jbiosc. 2013.06 .007

30 Galvin S, Cahill O, O'Connor N, Cafolla AA, Daniels S and Humphreys $\mathrm{H}$ : The antimicrobial effects of helium and heliumair plasma on staphylococcus aureus and clostridium difficile. Lett Appl Microbiol 57(2): 83-90, 2013. PMID: 23607860. DOI: 10.1111/lam.12091

31 Hamza E, Dorgham SM and Hamza DA: Carbapenemaseproducing klebsiella pneumoniae in broiler poultry farming in egypt. J Glob Antimicrob Resist 7: 8-10, 2016. PMID: 27530998. DOI: 10.1016/j.jgar.2016.06.004

32 Aires-de-Sousa M: Methicillin-resistant staphylococcus aureus among animals: Current overview. Clin Microbiol Infect 23(6): 373-380, 2017. PMID: 27851997. DOI: 10.1016/j.cmi.2016. 11.002

33 Andres-Lasheras S, Bolea R, Mainar-Jaime RC, Kuijper E, Sevilla E, Martin-Burriel I and Chirino-Trejo M: Presence of clostridium difficile in pig faecal samples and wild animal species associated with pig farms. J Appl Microbiol 122(2): 462-472, 2017. PMID: 27990723. DOI: 10.1111/jam.13343

34 Yuan YG, Peng QL and Gurunathan S: Effects of silver nanoparticles on multiple drug-resistant strains of staphylococcus aureus and pseudomonas aeruginosa from mastitis-infected goats: An alternative approach for antimicrobial therapy. Int J Mol Sci 18(3), 2017. PMID: 28272303. DOI: 10.3390/ijms18030569

35 Al Bayssari C, Dabboussi F, Hamze $M$ and Rolain JM: Emergence of carbapenemase-producing pseudomonas aeruginosa and acinetobacter baumannii in livestock animals in lebanon. $\mathbf{J}$ Antimicrob Chemother 70(3): 950-951, 2015. PMID: 25406297. DOI: $10.1093 / \mathrm{jac} / \mathrm{dku} 469$

36 Julak J, Souskova H, Scholtz V, Kvasnickova E, Savicka D and Kriha V: Comparison of fungicidal properties of non-thermal plasma produced by corona discharge and dielectric barrier discharge. Folia Microbiol (Praha) 63(1): 63-68, 2018. PMID: 28623536. DOI: 10.1007/s12223-017-0535-6

37 Souskova H, Scholtz V, Julak J, Kommova L, Savicka D and Pazlarova J: The survival of micromycetes and yeasts under the low-temperature plasma generated in electrical discharge. Folia Microbiol (Praha) 56(1): 77-79, 2011. PMID: 21399943. DOI: 10.1007/s12223-011-0005-5

38 Liao X, Xiang Q, Liu D, Chen S, Ye X and Ding T: Lethal and sublethal effect of a dielectric barrier discharge atmospheric cold plasma on staphylococcus aureus. J Food Prot 80(6): 928932, 2017. PMID: 28459615. DOI: 10.4315/0362-028X.JFP$16-499$ 
39 Joshi SG, Cooper M, Yost A, Paff M, Ercan UK, Fridman G, Friedman G, Fridman A and Brooks AD: Nonthermal dielectricbarrier discharge plasma-induced inactivation involves oxidative DNA damage and membrane lipid peroxidation in Escherichia coli. Antimicrob Agents Chemother 55(3): 10531062, 2011. PMID: 21199923. DOI: 10.1128/AAC.01002-10

40 Moisan M, Barbeau J, Moreau S, Pelletier J, Tabrizian M and Yahia LH: Low-temperature sterilization using gas plasmas: A review of the experiments and an analysis of the inactivation mechanisms. Int J Pharm 226(1-2): 1-21, 2001. PMID: 11532565.

41 Alkawareek MY, Gorman SP, Graham WG and Gilmore BF: Potential cellular targets and antibacterial efficacy of atmospheric pressure non-thermal plasma. Int $\mathrm{J}$ Antimicrob Agents 43(2): 154-160, 2014. PMID: 24139886. DOI: $10.1016 /$ j.ijantimicag.2013.08.022

42 Sohbatzadeh F, Hosseinzadeh Colagar A, Mirzanejhad S and Mahmodi S: E. Coli, p. Aeruginosa, and b. Cereus bacteria sterilization using afterglow of non-thermal plasma at atmospheric pressure. Appl Biochem Biotechnol 160(7): 1978-1984, 2010. PMID: 19882114. DOI: 10.1007/s12010-009-8817-3

43 Park JH, Kumar N, Park DH, Yusupov M, Neyts EC, Verlackt CC, Bogaerts A, Kang MH, Uhm HS, Choi EH and Attri P: A comparative study for the inactivation of multidrug resistance bacteria using dielectric barrier discharge and nano-second pulsed plasma. Sci Rep 5: 13849, 2015. PMID: 26351132. DOI: 10.1038/srep13849

44 Park JS, Kim K, Han JH, Gweon B, Ko UH, Yoo SJ, Choe W and Shin JH: Effects of minimal exposures to atmospheric pressure plasma on the activity of salmonella typhimurium: Deactivation of bacterial motility and suppression of host-cell invasion. Arch Biochem Biophys 605: 67-75, 2016. PMID: 27345896. DOI: 10.1016/j.abb.2016.06.012.

45 Cotter JJ, Maguire P, Soberon F, Daniels S, O'Gara JP and Casey E: Disinfection of meticillin-resistant staphylococcus aureus and staphylococcus epidermidis biofilms using a remote non-thermal gas plasma. J Hosp Infect 78(3): 204-207, 2011. PMID: 21601949. DOI: 10.1016/j.jhin.2011.03.019

$46 \mathrm{Xu} \mathrm{L}, \mathrm{Tu}$ Y, Yu Y, Tan M, Li J and Chen H: Augmented survival of neisseria gonorrhoeae within biofilms: Exposure to atmospheric pressure non-thermal plasmas. Eur $\mathrm{J}$ Clin Microbiol Infect Dis 30(1): 25-31, 2011. PMID: 20839022. DOI: $10.1007 / \mathrm{s} 10096-010-1047-3$

47 Fricke K, Koban I, Tresp H, Jablonowski L, Schroder K, Kramer A, Weltmann KD, von Woedtke $\mathrm{T}$ and Kocher T: Atmospheric pressure plasma: A high-performance tool for the efficient removal of biofilms. PLoS One 7(8): e42539, 2012 PMID: 22880025. DOI: 10.1371/journal.pone.0042539

48 Julak J, Scholtz V and Vankova E: Medically important biofilms and non-thermal plasma. World J Microbiol Biotechnol 34(12): 178, 2018. PMID: 30456518. DOI: 10.1007/s11274018-2560-2

49 Shintani H: Inactivation of bacterial spore, endotoxin, lipid a, normal prion and abnormal prion by exposures to several sorts of gases plasma. Biocontrol Sci 21(1): 1-12, 2016. PMID: 27009504. DOI: $10.4265 /$ bio.21.1

50 Vandervoort KG and Brelles-Marino G: Plasma-mediated inactivation of pseudomonas aeruginosa biofilms grown on borosilicate surfaces under continuous culture system. PLoS One 9(10): e108512, 2014. PMID: 25302815. DOI: 10.1371/journal.pone. 0108512
51 Di Martino G, Piccirillo A, Giacomelli M, Comin D, Gallina A, Capello K, Buniolo F, Montesissa C and Bonfanti L: Microbiological, chemical and physical quality of drinking water for commercial turkeys: A cross-sectional study. Poultry Sci 97(8): 2880-2886, 2018. PMID: 29672773. DOI: 10.3382/ ps/pey 130

52 Dolezalova E and Lukes P: Membrane damage and active but nonculturable state in liquid cultures of Escherichia coli treated with an atmospheric pressure plasma jet. Bioelectrochemistry 103: 7-14, 2015. PMID: 25212700. DOI: 10.1016/j.bioelechem. 2014.08.018

53 Jiang X, Lee S, Mok C and Lee J: Sustainable methods for decontamination of microcystin in water using cold plasma and uv with reusable tio(2) nanoparticle coating. Int J Environ Res Public Health 14(5), 2017. PMID: 28475156. DOI: 10.3390/ ijerph14050480

$54 \mathrm{Li} \mathrm{L}$, Zhang $\mathrm{H}$ and Huang Q: New insight into the residual inactivation of microcystis aeruginosa by dielectric barrier discharge. Sci Rep 5: 13683, 2015. PMID: 26347270. DOI: $10.1038 /$ srep 13683

55 Hayes J, Kirf D, Garvey M and Rowan N: Disinfection and toxicological assessments of pulsed uv and pulsed-plasma gasdischarge treated-water containing the waterborne protozoan enteroparasite cryptosporidium parvum. J Microbiol Methods 94(3): 325-337, 2013. PMID: 23892042. DOI: 10.1016/ j.mimet.2013.07.012

56 El-Sayed WS, Ouf SA and Mohamed AA: Deterioration to extinction of wastewater bacteria by non-thermal atmospheric pressure air plasma as assessed by 16 s rdna-dgge fingerprinting. Front Microbiol 6: 1098, 2015. PMID: 26500637. DOI: 10.3389/fmicb. 2015.01098

57 Trovó AG, Melo SAS and Nogueira RFP: Photodegradation of the pharmaceuticals amoxicillin, bezafibrate and paracetamol by the photo-fenton process-application to sewage treatment plant effluent. J Photochem Photobiol A Chem 198(2-3): 215220, 2008. DOI: $10.1016 /$ j.jphotochem.2008.03.011

58 Vanraes P, Willems G, Daels N, Van Hulle SW, De Clerck K, Surmont P, Lynen F, Vandamme J, Van Durme J, Nikiforov A and Leys C: Decomposition of atrazine traces in water by combination of non-thermal electrical discharge and adsorption on nanofiber membrane. Water Res 72: 361-371, 2015. PMID: 25482844. DOI: 10.1016/j.watres.2014.11.009

59 Mountapmbeme-Kouotou P, Laminsi S, Acayanka E and Brisset JL: Degradation of palm oil refinery wastewaters by nonthermal gliding arc discharge at atmospheric pressure. Environ Monit Assess 185(7): 5789-5800, 2013. PMID: 23229278. DOI: 10.1007/s10661-012-2984-3

60 Benetoli LO, Cadorin BM, Baldissarelli VZ, Geremias R, de Souza IG and Debacher NA: Pyrite-enhanced methylene blue degradation in non-thermal plasma water treatment reactor. J Hazard Mater 237-238: 55-62, 2012. PMID: 22980582. DOI: 10.1016/j.jhazmat.2012.07.067

61 Magureanu M, Mandache NB and Parvulescu VI: Degradation of pharmaceutical compounds in water by non-thermal plasma treatment. Water Res 81: 124-136, 2015. PMID: 26057260. DOI: $10.1016 /$ j.watres.2015.05.037

62 Banaschik R, Lukes P, Jablonowski H, Hammer MU, Weltmann $\mathrm{KD}$ and Kolb JF: Potential of pulsed corona discharges generated in water for the degradation of persistent pharmaceutical residues. Water Res 84: 127-135, 2015. PMID: 26218466. DOI: $10.1016 /$ j.watres.2015.07.018 
63 Bansode AS, More SE, Siddiqui EA, Satpute S, Ahmad A, Bhoraskar SV and Mathe VL: Effective degradation of organic water pollutants by atmospheric non-thermal plasma torch and analysis of degradation process. Chemosphere 167: 396-405, 2017. PMID: 27744197. DOI: 10.1016/j.chemosphere. 2016.09. 089

64 Garcia MC, Mora M, Esquivel D, Foster JE, Rodero A, JimenezSanchidrian C and Romero-Salguero FJ: Microwave atmospheric pressure plasma jets for wastewater treatment: Degradation of methylene blue as a model dye. Chemosphere 180: 239-246, 2017. PMID: 28411539. DOI: 10.1016/j. chemosphere.2017.03.126

65 Magureanu M, Piroi D, Mandache NB, David V, Medvedovici A, Bradu C and Parvulescu VI: Degradation of antibiotics in water by non-thermal plasma treatment. Water Res 45(11): 3407-3416, 2011. PMID: 21514950. DOI: 10.1016/j.watres. 2011.03.057

66 Lee D, Lee JC, Nam JY and Kim HW: Degradation of sulfonamide antibiotics and their intermediates toxicity in an aeration-assisted non-thermal plasma while treating strong wastewater. Chemosphere 209: 901-907, 2018. PMID: 30114739. DOI: 10.1016/j.chemosphere.2018.06.125

67 Zhao H, Ding M, Gao Y and Deng W: Determination of sulfonamides in pork, egg, and chicken using multiwalled carbon nanotubes as a solid-phase extraction sorbent followed by ultra-performance liquid chromatography/tandem mass spectrometry. J AOAC Int 97(5): 1481-1488, 2014. PMID: 25903004. DOI: $10.5740 /$ jaoacint.13-133

68 Giardina A, Tampieri F, Marotta E and Paradisi C: Air nonthermal plasma treatment of irgarol 1051 deposited on tio2. Chemosphere 210: 653-661, 2018. PMID: 30031349. DOI: 10.1016/j.chemosphere.2018.07.012

69 Bradu C, Magureanu M and Parvulescu VI: Degradation of the chlorophenoxyacetic herbicide 2,4-d by plasma-ozonation system. J Hazard Mater 336: 52-56, 2017. PMID: 28472708. DOI: $10.1016 /$ j.jhazmat.2017.04.050

70 Vilarrasa E, Barroeta AC, Tres A and Esteve-Garcia E: Use of re-esterified palm oils, differing in their acylglycerol structure, in weaning-piglet diets. Animal 9(8): 1304-1311, 2015. PMID: 25912649. DOI: $10.1017 / \mathrm{S} 1751731115000622$

71 Bianchi AE, Silva ASD, Biazus AH, Richards N, Pellegrini LG, Baldissera MD, Macedo VP and Silveira A: Adding palm oil to the diet of sheep alters fatty acids profile on yogurt: Benefits to consumers. An Acad Bras Cienc 89(3 Suppl): 2471-2478, 2017. PMID: 29091111. DOI: 10.1590/0001-376520172 0170468

72 Todorova Y, Yotinov I, Topalova Y, Benova E, Marinova P, Tsonev I and Bogdanov T: Evaluation of the effect of cold atmospheric plasma on oxygenases' activities for application in water treatment technologies. Environ Technol: 1-10, 2018. PMID: 29923777. DOI: 10.1080/09593330.2018.1491631

73 Niinemets U, Loreto F and Reichstein M: Physiological and physicochemical controls on foliar volatile organic compound emissions. Trends Plant Sci 9(4): 180-186, 2004. PMID: 15063868. DOI: $10.1016 /$ j.tplants.2004.02.006

74 Yao Q, Torrents A, Li H, Buser MD, McConnell LL, Downey PM and Hapeman CJ: Using a vegetative environmental buffer to reduce the concentrations of volatile organic compounds in poultryhouse atmospheric emissions. J Agric Food Chem 66(31): 82318236, 2018. PMID: 29957951. DOI: 10.1021/ acs.jafc.8b00088

75 Ni JQ, Robarge WP, Xiao C and Heber AJ: Volatile organic compounds at swine facilities: A critical review. Chemosphere 89(7): 769-788, 2012. PMID: 22682363. DOI: 10.1016/ j.chemosphere.2012.04.061
76 Laor Y, Koziel JA, Cai L and Ravid U: Chemical-sensory characterization of dairy manure odor using headspace solidphase microextraction and multidimensional gas chromatography mass spectrometry-olfactometry. J Air Waste Manag Assoc 58(9): 1187-1197, 2008. PMID: 18817111.

77 Hirota K, Sakai H, Washio M and Kojima T: Application of electron beams for the treatment of voc streams. Ind Eng Chem Res 43(5): 1185-1191, 2004. DOI: 10.1021/ie0340746

78 Subrahmanyam C, Renken A and Kiwi-Minsker L: Novel catalytic non-thermal plasma reactor for the abatement of vocs. Chem Eng J 134(1): 78-83, 2007. DOI: 10.1016/ j.cej.2007.03.063

79 Urashima K and Jen-Shih C: Removal of volatile organic compounds from air streams and industrial flue gases by nonthermal plasma technology. IEEE T Dielect El In 7(5): 602-614, 2000. DOI: $10.1109 / 94.879356$

80 Van Durme J, Dewulf J, Sysmans W, Leys C and Van Langenhove $\mathrm{H}$ : Efficient toluene abatement in indoor air by a plasma catalytic hybrid system. Appl Catal B 74(1): 161-169, 2007. DOI: 10.1016/j.apcatb.2007.02.006

81 Preis S, Klauson D and Gregor A: Potential of electric discharge plasma methods in abatement of volatile organic compounds originating from the food industry. J Environ Manage 114: 125-138, 2013. PMID: 23238056. DOI: 10.1016/ j.jenvman.2012.10.042

82 Zhu T, Chen R, Xia N, Li X, He X, Zhao W and Carr T: Volatile organic compounds emission control in industrial pollution source using plasma technology coupled with ftio2/gamma-al2o3. Environ Technol 36(9-12): 1405-1413, 2015. PMID: 25428439. DOI: 10.1080/09593330.2014.992479

83 Chang MB, Balbach JH, Rood MJ and Kushner MJ: Removal of so2 from gas streams using a dielectric barrier discharge and combined plasma photolysis. J Appl Phys 69(8): 4409-4417, 1991. DOI: $10.1063 / 1.348367$

84 Chang KS and Peng X: No presence effects on the reduction of n2o by co over al-pd-co oxide catalyst. J Ind Eng Chem 16(3): 455-460, 2010. DOI: 10.1016/j.jiec.2010.01.046

85 Young Sun M, Dors M and Mizerazcyk J: Effect of reaction temperature on no/sub $\mathrm{x} /$ removal and formation of ammonium nitrate in nonthermal plasma process combined with selective catalytic reduction. IEEE T Plasma Sci 32(2): 799-807, 2004. DOI: $10.1109 /$ TPS .2004 .826057

86 Chang Moo B and Tseng Tian D: Gas-phase removal of h2s and nh3 with dielectric barrier discharges. J Environl Eng 122(1): 41-46, 1996. DOI: 10.1061/(asce)0733-9372(1996)122:1(41)

87 Gal A, Ogata A, Futamura S and Mizuno K: Mechanism of the dissociation of chlorofluorocarbons during nonthermal plasma processing in nitrogen at atmospheric pressure. J Phys Chem A 107(42): 8859-8866, 2003. DOI: 10.1021/jp0347769

88 Radhakrishnan R, Oyama ST, Chen JG and Asakura K: Electron transfer effects in ozone decomposition on supported manganese oxide. J Phys Chem B 105(19): 4245-4253, 2001. DOI: $10.1021 /$ jp003246z

89 Preis S, Klauson D and Gregor A: Potential of electric discharge plasma methods in abatement of volatile organic compounds originating from the food industry. J Environ Manage 114: 125-138, 2013. PMID: 23238056. DOI: 10.1016/j.jenvman.2012. 10.042

90 Shin S, Hwang HJ and Song J: A combined process of non-thermal plasma with sludge stabilization for the simultaneous reduction of odor and organic waste. Water Sci Technol 64(12): 2389-2394, 2011. PMID: 22170832. DOI: 10.2166/wst. 2011.807 
91 Chen R, Xia N, Li X, He X, Zhao W and Carr T: Volatile organic compounds emission control in industrial pollution source using plasma technology coupled with f-tio $2 / \gamma$-al 203 au - zhu, tao. Environ Technol 36(11): 1405-1413, 2015. DOI: 10.1080/09593330.2014.992479

92 Wei ZS, Li HQ, He JC, Ye QH, Huang QR and Luo YW: Removal of dimethyl sulfide by the combination of non-thermal plasma and biological process. Bioresour Technol 146: 451456, 2013. PMID: 23954717. DOI: 10.1016/j.biortech. 2013.07.114

93 Ulmer JB, Valley U and Rappuoli R: Vaccine manufacturing: Challenges and solutions. Nat Biotechnol 24: 1377, 2006. PMID: 17093488. DOI: 10.1038/nbt1261

94 Laddy DJ and Weiner DB: From plasmids to protection: A review of DNA vaccines against infectious diseases. Int Rev Immunol 25(3-4): 99-123, 2006. PMID: 16818367. DOI: $10.1080 / 08830180600785827$

95 Tian G, Zeng X, Li Y, Shi J and Chen H: Protective efficacy of the h5 inactivated vaccine against different highly pathogenic $\mathrm{h} 5 \mathrm{n} 1$ avian influenza viruses isolated in china and vietnam. Avian Dis 54(1 Suppl): 287-289, 2010. PMID: 20521646. DOI: 10.1637/8707-031709-ResNote.1

96 Daszak P, Cunningham AA and Hyatt AD: Emerging infectious diseases of wildlife - threats to biodiversity and human health. Science 287(5452): 443-449, 2000. PMID: 10642539.

97 Alexander DJ: The epidemiology and control of avian influenza and newcastle disease. J Comp Pathol 112(2): 105-126, 1995. PMID: 7769142.

98 Qiu L, Zhang M, Tang J, Adhikari B and Cao P: Innovative technologies for producing and preserving intermediate moisture foods: A review. Food Res Int 116: 90-102, 2019. PMID: 30717022. DOI: 10.1016/j.foodres.2018.12.055

99 Pankaj SK, Wan Z and Keener KM: Effects of cold plasma on food quality: A review. Foods 7(1), 2018. PMID: 29301243. DOI: $10.3390 /$ foods 7010004

100 Afshari R and Hosseini H: Non-thermal plasma as a new food preservation method, its present and future prospect. J Paramed Sci 5(1), 2014. DOI: $10.22037 /$ jps.v5i1.5348

101 Van Impe J, Smet C, Tiwari B, Greiner R, Ojha S, Stulic V, Vukusic T and Rezek Jambrak A: State of the art of nonthermal and thermal processing for inactivation of micro-organisms. J Appl Microbiol 125(1): 16-35, 2018. PMID: 29502355. DOI: 10.1111/jam.13751

102 Calvo T, Alvarez-Ordonez A, Prieto M, Gonzalez-Raurich M and Lopez M: Influence of processing parameters and stress adaptation on the inactivation of listeria monocytogenes by non-thermal atmospheric plasma (ntap). Food Res Int 89(Pt 1): 631-637, 2016. PMID: 28460960. DOI: 10.1016/ j.foodres.2016.09.014

103 Attri P, Han J, Choi S, Choi EH, Bogaerts A and Lee W: Cap modifies the structure of a model protein from thermophilic bacteria: Mechanisms of cap-mediated inactivation. Sci Rep 8(1): 10218, 2018. PMID: 29977069. DOI: 10.1038/s41598018-28600-w

104 Kilonzo-Nthenge A, Liu S, Yannam S and Patras A: Atmospheric cold plasma inactivation of salmonella and Escherichia coli on the surface of golden delicious apples. Front Nutr 5: 120, 2018. PMID: 30619867. DOI: 10.3389/fnut. 2018.00120

105 Fernandez A, Noriega E and Thompson A: Inactivation of salmonella enterica serovar typhimurium on fresh produce by cold atmospheric gas plasma technology. Food Microbiol 33(1): 24-29, 2013. PMID: 23122497. DOI: 10.1016/j.fm.2012.08.007

106 Gurol C, Ekinci FY, Aslan N and Korachi M: Low temperature plasma for decontamination of e. Coli in milk. Int J Food Microbiol 157(1): 1-5, 2012. PMID: 22622128. DOI: 10.1016/ j.ijfoodmicro.2012.02.016

107 van Bokhorst-van de Veen H, Xie H, Esveld E, Abee T, Mastwijk $\mathrm{H}$ and Nierop Groot M: Inactivation of chemical and heat-resistant spores of bacillus and geobacillus by nitrogen cold atmospheric plasma evokes distinct changes in morphology and integrity of spores. Food Microbiol 45(Pt A): 26-33, 2015. PMID: 25481059. DOI: 10.1016/j.fm.2014.03.018

108 Streit E, Naehrer K, Rodrigues I and Schatzmayr G: Mycotoxin occurrence in feed and feed raw materials worldwide: Longterm analysis with special focus on europe and asia. Journal of the Science of Food and Agriculture 93(12): 2892-2899, 2013. PMID: 23670211. DOI: $10.1002 /$ jsfa.6225

109 Basaran P, Basaran-Akgul N and Oksuz L: Elimination of aspergillus parasiticus from nut surface with low pressure cold plasma (LPCP) treatment. Food Microbiol 25(4): 626-632, 2008. PMID: 18456118. DOI: 10.1016/j.fm.2007.12.005

110 Herceg Z, Rezek Jambrak A, Vukusic T, Stulic V, Stanzer D and Milosevic S: The effect of high-power ultrasound and gas phase plasma treatment on aspergillus spp. And penicillium spp. Count in pure culture. J Appl Microbiol 118(1): 132-141, 2015. PMID: 25393164. DOI: 10.1111/jam.12692

111 Dorraki N, Mahdavi V, Ghomi H and Ghasempour A: Elimination of diazinon insecticide from cucumber surface by atmospheric pressure air-dielectric barrier discharge plasma. Biointerphases 11(4): 041007, 2016. PMID: 27923272. DOI: $10.1116 / 1.4971382$

112 Heinlin J, Morfill G, Landthaler M, Stolz W, Isbary G, Zimmermann JL, Shimizu T and Karrer S: Plasma medicine: Possible applications in dermatology. J Dtsch Dermatol Ges 8(12): 968-976, 2010. PMID: 20718902. DOI: 10.1111/j.16100387.2010.07495.x

113 Heinlin J, Isbary G, Stolz W, Morfill G, Landthaler M, Shimizu T, Steffes B, Nosenko T, Zimmermann J and Karrer S: Plasma applications in medicine with a special focus on dermatology. J Eur Acad Dermatol Venereol 25(1): 1-11, 2011. PMID: 20497290. DOI: 10.1111/j.1468-3083.2010.03702.x.

114 Daeschlein G, Scholz S, Ahmed R, von Woedtke T, Haase H, Niggemeier M, Kindel E, Brandenburg R, Weltmann KD and Juenger M: Skin decontamination by low-temperature atmospheric pressure plasma jet and dielectric barrier discharge plasma. J Hosp Infect 81(3): 177-183, 2012. PMID: 22682918. DOI: $10.1016 /$ j.jhin.2012.02.012

115 Ermolaeva SA, Sysolyatina EV, Kolkova NI, Bortsov P, Tuhvatulin AI, Vasiliev MM, Mukhachev AY, Petrov OF, Tetsuji S, Naroditsky BS, Morfill GE, Fortov VE, Grigoriev AI, Zigangirova NA and Gintsburg AL: Non-thermal argon plasma is bactericidal for the intracellular bacterial pathogen chlamydia trachomatis. J Med Microbiol 61(Pt 6): 793-799, 2012. PMID: 22361459. DOI: $10.1099 / \mathrm{jmm} .0 .038117-0$

116 Mohd Nasir N, Lee BK, Yap SS, Thong KL and Yap SL: Cold plasma inactivation of chronic wound bacteria. Arch Biochem Biophys 605: 76-85, 2016. PMID: 27046340. DOI: 10.1016/ j.abb.2016.03.033

117 Kisch T, Schleusser S, Helmke A, Mauss KL, Wenzel ET, Hasemann B, Mailaender P and Kraemer R: The repetitive use 
of non-thermal dielectric barrier discharge plasma boosts cutaneous microcirculatory effects. Microvasc Res 106: 8-13, 2016. PMID: 26944583. DOI: 10.1016/j.mvr.2016.02.008

118 Nomura Y, Takamatsu T, Kawano H, Miyahara H, Okino A, Yoshida $\mathrm{M}$ and Azuma T: Investigation of blood coagulation effect of nonthermal multigas plasma jet in vitro and in vivo. J Surg Res 219: 302-309, 2017. PMID: 29078897. DOI: 10.1016/j.jss.2017.06.055

119 Arjunan KP, Friedman G, Fridman A and Clyne AM: Nonthermal dielectric barrier discharge plasma induces angiogenesis through reactive oxygen species. J R Soc Interface 9(66): 147157, 2012. PMID: 21653568. DOI: 10.1098/ rsif.2011.0220

120 Kubinova S, Zaviskova K, Uherkova L, Zablotskii V, Churpita $\mathrm{O}$, Lunov $\mathrm{O}$ and Dejneka A: Non-thermal air plasma promotes the healing of acute skin wounds in rats. Sci Rep 7: 45183, 2017. PMID: 28338059. DOI: 10.1038/srep45183

121 Haertel B, von Woedtke T, Weltmann KD and Lindequist U: Non-thermal atmospheric-pressure plasma possible application in wound healing. Biomol Ther (Seoul) 22(6): 477-490, 2014. PMID: 25489414. DOI: 10.4062/biomolther.2014.105

$122 \mathrm{Wu}$ AS, Kalghatgi S, Dobrynin D, Sensenig R, Cerchar E, Podolsky E, Dulaimi E, Paff M, Wasko K, Arjunan KP, Garcia K, Fridman G, Balasubramanian M, Ownbey R, Barbee KA, Fridman A, Friedman G, Joshi SG and Brooks AD: Porcine intact and wounded skin responses to atmospheric nonthermal plasma. J Surg Res 179(1): e1-e12, 2013. PMID: 22480830. DOI: $10.1016 /$ j.jss.2012.02.039

123 Park YH, Kim HS, Lee JH, Choi SA, Kim JM, Oh GT, Kang SW, Kim SU and Yu DY: Peroxiredoxin i participates in the protection of reactive oxygen species-mediated cellular senescence. BMB Rep 50(10): 528-533, 2017. PMID: 28893373. DOI: 10.5483/BMBRep.2017.50.10.121

124 West MD: The cellular and molecular biology of skin aging. Arch Dermatol 130(1): 87-95, 1994. PMID: 8285746.

125 Choi JH, Song YS, Song K, Lee HJ, Hong JW and Kim GC: Skin renewal activity of non-thermal plasma through the activation of beta-catenin in keratinocytes. Sci Rep 7(1): 6146, 2017. PMID: 28733577. DOI: 10.1038/s41598-017-06661-7

126 Limsopatham K, Boonyawan D, Umongno C, Sukontason KL, Chaiwong T, Leksomboon R and Sukontason K: Effect of cold argon plasma on eggs of the blow fly, lucilia cuprina (diptera: Calliphoridae). Acta Trop 176: 173-178, 2017. PMID: 28802553. DOI: 10.1016/j.actatropica.2017.08.005

127 Rahman M, Tanino M, Hashimoto M, Nakano M, Yasuda H, Takashima K and Mizuno A: Fundamental study on quasi-realtime detection of airborne bio-particles using discharge plasma. Thin Solid Films 516(19): 6699-6703, 2008. DOI: 10.1016/ j.tsf.2007.11.043

128 Liang Y, Wu Y, Sun K, Chen Q, Shen F, Zhang J, Yao M, Zhu $\mathrm{T}$ and Fang J: Rapid inactivation of biological species in the air using atmospheric pressure nonthermal plasma. Environ Sci Technol 46(6): 3360-3368, 2012. PMID: 22385302. DOI: $10.1021 / \mathrm{es} 203770 \mathrm{q}$

129 Moritz M, Peters H, Nipko B and Ruden H: Capability of air filters to retain airborne bacteria and molds in heating, ventilating and air-conditioning (hvac) systems. Int J Hyg Environ Health 203(5-6): 401-409, 2001. PMID: 11556144. DOI: $10.1078 / 1438-4639-00054$
130 Mizuno A: Destruction of biological particles using non-thermal plasma. J Clin Biochem Nutr 60(1): 12-24, 2017. PMID: 28163377. DOI: $10.3164 /$ jcbn.16-64

131 Park CW and Hwang J: Susceptibility constants of airborne bacteria to dielectric barrier discharge for antibacterial performance evaluation. J Hazard Mater 244-245: 421-428, 2013. PMID: 23274942. DOI: 10.1016/j.jhazmat.2012.12.006.

$132 \mathrm{Wu}$ Y, Liang Y, Wei K, Li W, Yao M, Zhang J and Grinshpun SA: Ms2 virus inactivation by atmospheric-pressure cold plasma using different gas carriers and power levels. Appl Environ Microbiol 81(3): 996-1002, 2015. PMID: 25416775. DOI: 10.1128/AEM.03322-14

133 Vaze ND, Park S, Brooks AD, Fridman A and Joshi SG: Involvement of multiple stressors induced by non-thermal plasma-charged aerosols during inactivation of airborne bacteria. PLOS ONE 12(2): e0171434, 2017. PMID: 28166240. DOI: 10.1371 /journal.pone.0171434

134 Bunz O, Mese K, Zhang W, Piwowarczyk A and Ehrhardt A: Effect of cold atmospheric plasma (cap) on human adenoviruses is adenovirus type-dependent. PLoS One 13(10): e0202352, 2018. PMID: 30365500. DOI: 10.1371/journal.pone.0202352

135 Ziuzina D, Patil S, Cullen PJ, Keener KM and Bourke P: Atmospheric cold plasma inactivation of Escherichia coli in liquid media inside a sealed package. J Appl Microbiol 114(3): 778-787, 2013. PMID: 23190122. DOI: 10.1111/jam.12087

136 Ben Belgacem Z, Carre G, Charpentier E, Le-Bras F, Maho T, Robert E, Pouvesle JM, Polidor F, Gangloff SC, Boudifa M and Gelle MP: Innovative non-thermal plasma disinfection process inside sealed bags: Assessment of bactericidal and sporicidal effectiveness in regard to current sterilization norms. PLoS One 12(6): e0180183, 2017. PMID: 28662202. DOI: 10.1371/ journal.pone. 0180183

137 Misra NN, Keener KM, Bourke P, Mosnier JP and Cullen PJ: In-package atmospheric pressure cold plasma treatment of cherry tomatoes. J Biosci Bioeng 118(2): 177-182, 2014. PMID: 24650730. DOI: 10.1016/j.jbiosc.2014.02.005

138 Wang J, Zhuang H, Hinton A, Jr. and Zhang J: Influence of inpackage cold plasma treatment on microbiological shelf life and appearance of fresh chicken breast fillets. Food Microbiol 60: 142-146, 2016. PMID: 27554156. DOI: 10.1016/j.fm.2016. 07.007

139 Song AY, Oh YA, Roh SH, Kim JH and Min SC: Cold oxygen plasma treatments for the improvement of the physicochemical and biodegradable properties of polylactic acid films for food packaging. J Food Sci 81(1): E86-96, 2016. PMID: 26646616. DOI: $10.1111 / 1750-3841.13172$ 